\title{
Clonal selection in cacao based on early yield performance of grafted trees ${ }^{1,2}$
}

\author{
Héber Irizarry.3 and Ricardo Goenaga
}

J. Agric Univ. P.R. 84(3-4):153-163 (2000)

\begin{abstract}
An experiment with 45 Theobroma cacao $L$. clones grafted onto a common rootstock was established between September 1991 and November 1997 to determine the yield potential of trees selected from interclonal families. Scionwood of 40 promising trees selected from among 1,320 trees, representing five families and three locations in Puerto Rico, were patch bud grafted onto the rootstock clone EET-400. Additionally, scionwood of five of the eight parental clones involved in the combination of the families was also grafted onto the same rootstock. The $\mathbf{4 5}$ treatments were arranged in a randomized complete block design with six replications, each containing two experimental trees per replication. The trees reached full production in 1994, during the third growing year. Between 1994 and 1997 the mature pods were harvested, and the dry bean weight and pod index were determined. The means of the $\mathbf{4 0}$ grafted selections were compared with the combined means of five parental clones or to the mean of their highest yielding parent $(P \leq 0.01)$. At the termination of the experiment in November 1997, only nine of the grafted clones significantly outyielded their parents, with a mean production of $2,170 \mathrm{~kg} / \mathrm{ha} /$ year of dry beans. This finding indicated that fewer than $1 \%$ of the trees in the original five-family population were exceptionally superior yielders. Five of the nine superior yielding clones also had a significantly higher pod index. None of the 16 clones representing families IMC-67 $\times$ SCA-12 and IMC-67 $\times$ UF-613 performed as superior yielders. We concluded that either one or both parents involved in these interclonal crosses lack combining ability and may be excluded from cacao improvement programs. In addition, we found a direct relation between high pod index and superior dry bean weight in the progeny of family SCA-6 $\times$ EET-62.
\end{abstract}

Keywords: cacao, clone selection, yield, pod index

'Manuscripl submitted to Editorial Board 8 December 1999.

2This paper covers work carried out cooperatively between the Agricultural Research Service-USDA and the Agricultural Experiment Station, University of Puerto Rico (AES-UPR), Río Piedras, Puerto Rico, and the Americun Cacao Research Institute, McLean, Virginia (Agreement No. 58-32UA-0-114). The authors thank Nicolás Diaz and Javier Fuentes, Agricultural Research Technicians, for their cooperation in carrying out the experiment.

${ }^{3}$ Research Horticulturist, Tropical Agriculture Research Station, 2200 Pedro Albizu Campos Ave., Suite 201, Mayagüez, PR 00680-5470.

${ }^{4}$ Research Plant Physiologist, Tropical Agxiculture Research Station, 2200 Pedro Albizu Campos Ave., Suite 201, Mayagüez, PR 00680-5470. 


\section{RESUMEN}

\section{Selección clonal en cacao a base del rendimiento temprano} de árboles injertados

Entre septiembre 1991 y noviembre 1997 se evaluaron 45 clones injertados de Theobroma cacao $L$. para determinar el potencial de rendimiento de árboles seleccionados de cinco familias interclonales. Yemas de $\mathbf{4 0}$ árboles de alto rendimiento, seleccionados de entre 1,320 árboles que representaban cinco familias y tres localidades de Puerto Rico, se injertaron en un patrón común, el clon EET-400. Además, yemas de cinco de los ocho clones parentales utilizados en las combinaciones de las familias también se injertaron en el mismo patrón. Los 45 tratamientos se distribuyeron en un diseño experimental de bloques completos al azar con seis replicaciones, dos árboles experimentales por tratamiento y replicación. Los árboles produjeron la primera cosecha completa en el 1994, durante el tercer año de crecimiento. Entre el 1994 y el 1997 se cosecharon las mazorcas, se obtuvo el peso seco de las almendras y se determinó el índice de mazorca por árbol. Los 40 clones seleccionados se compararon con el promedio combinado de los cinco clones parentales y con el promedio correspondiente al clon parental de mayor rendimiento. Al terminar el experimento en noviembre de 1997, nueve de los 40 clones originalmente seleccionados demostraron un potencial de rendimiento altamente significativo con una producción media de $2,170 \mathrm{~kg} / \mathrm{ha} / \mathrm{año}$ de almendras secas. Los resultados indicaron que menos del $1 \%$ de los árboles que componian la población total de las cinco familias eran productores superiores. Cinco de los nueve clones de alto rendimiento también tenian un índice de mazorca superior. Ninguno de los 16 clones seleccionados de las familias IMC-67 $\times$ SCA-12 y IMC-67 $\times$ UF-613 produjeron rendimientos superiores. A base de estos resultados se concluye que los padres involucrados en estos cruces interclonales carecen de aptitud combinatoria y pudieran ser excluidos de los programas de mejoramiento de cacao. Además, se encontró una relación directa entre el alto índice de mazorcas y un rendimiento mayor en la progenie de la familia SCA- $6 \times$ EET-62.

\section{INTRODUCTION}

The decline of the sugarcane industry in Puerto Rico has made available large acreage of agricultural land that is currently underutilized. This situation has created the necessity of finding substitute crops with agronomic potential for the efficient use of this idle land. In recent years one of the crops that has been evaluated under various agroenvironments and with intensive management is cacao (Irizarry and Rivera, 1998). Cacao has great potential as a component of a small farming system: It adapts to a wide range of soils and climatic conditions, grows well under minimum tillage, adapts to temporary intercropping with plantain or banana, has the potential of being sold in local and export markets, and the pods are harvested year-round, providing a ready source of cash income.

Under a commercial production system, it is highly recommended that cacao be propagated by the use of control-pollinated seed obtained from crosses of two or more parental clones (Batista, 1981; Wood and 
Lass, 1985). The use of this so-called "hybrid seed" is considered the simplest and cheapest method of cacao propagation, and may offer the opportunity to assemble into a single tree useful traits from distant parents (Enríquez and Soria, 1984; Enríquez and Paredes, 1985). Other proponents also consider the use of control-pollinated seed as the most useful means of increasing cacao production (Hunter, 1990). In most cases, however, the data available to support the high yielding assumption attributed to control-pollinated seed or the whole family progeny are based only on the production obtained from a few unique segregating " $F_{1}$ " trees. Additionally, the yield data needed from longterm experiments to validate this assumption are not available.

In a recent multisite experiment, Irizarry and Rivera (1998) studied the yield potential of five interclonal cacao farnilies over a period of eight harvested years at Corozal and Gurabo, and over four years at Yabucoa. They concluded that the high yielding capacity attributed to cacao families was confined to only a few superior trees. To test further this hypothesis, we grafted these high-yielding trees onto a common rootstock and proceeded to evaluate the potential candidates under full sunlight and intensive managernent.

\section{MATERIALS AND METHODS}

An experiment with 45 Theobroma cacao L. clones grafted onto a common rootstock was established between 20 September 1991 and 4 November 1997 at the Corozal Substation (AES-UPR). The substation is located in the north-central upland region $\left(18^{\circ} 20^{\prime} \mathrm{N}, 66^{\circ} 18^{\prime} \mathrm{E}\right.$; elevation $195 \mathrm{~m}$ ). During the experimental period the mean monthly maximum and minimum temperatures were $30.1^{\circ} \mathrm{C}$ and $18.9^{\circ} \mathrm{C}$, respectively. Mean monthly rainfall was $136.7 \mathrm{~mm}$ and Class A pan evaporation was $118.4 \mathrm{~mm}$. The experiment was conducted under rainfed conditions with fairly defined moisture deficits occurring during the months of February through April, and June and July of each year.

The soil, a Corozal clay, is a typical highly weathered soil (clayey, mixed isohyperthermic Aquic Haplohumults). The top 25-cm layer contains $2.2 \mathrm{mg} / \mathrm{kg}$ of "available" P (Bray method 2), and a cation exchange capacity of $11.2 \mathrm{cmol}(+) / \mathrm{kg}$ of soil. During soil preparation, ground limestone was applied at the rate of $5.6 \mathrm{t} / \mathrm{ha}$ to increase the soil $\mathrm{pH}$ to about 5.3 .

Scionwood of 40 high yielding trees, selected from among 1,320 trees representing five families grown at three locations in Puerto Rico (Table 1), was patch bud grafted below the cotyledons onto five-month-old open pollinated seedlings of clone EET-400. These unique trees were chosen because they demonstrated a consistent high yielding capacity during 
TABI,A 1.- Mean yield of 40 promising cacan selections obtained from five families and three locations in Puerto Rico during two harvest periods, 1986-1989 and $1994-1997$.

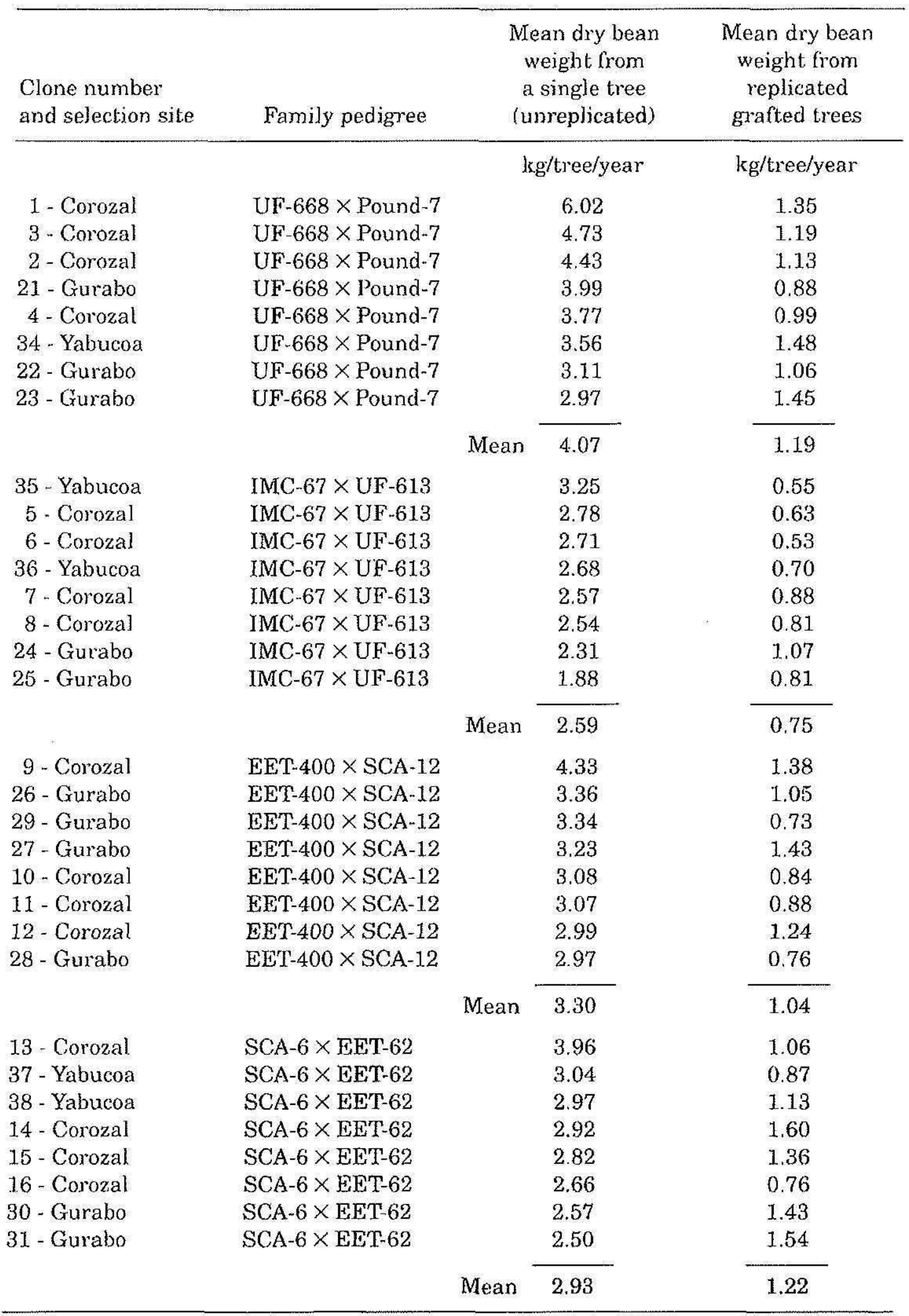


TABLE 1.-(CON'LNLED) Mean yield of 40 promising cacao selections obtained from five families and three locations in Puerto Rico during two harvest periods, 1986 1989 and 1994-1997.

\begin{tabular}{|c|c|c|c|}
\hline $\begin{array}{l}\text { Clone number } \\
\text { and selection site }\end{array}$ & Family pedigree & $\begin{array}{l}\text { Mean dry bean } \\
\text { weight from } \\
\text { a single tree } \\
\text { (unreplicated) }\end{array}$ & $\begin{array}{l}\text { Mean dry bean } \\
\text { weight from } \\
\text { replicated } \\
\text { grafted trees }\end{array}$ \\
\hline & & $\mathrm{kg} /$ tree/year & kg/tree/year \\
\hline 39 - Yabucoa & IMC- $67 \times$ SCA- 12 & 4.18 & 1.03 \\
\hline 17. Corozal & IMC- $67 \times$ SCA-12 & 3.30 & 0.91 \\
\hline 40 - Yabucoa & IMC- $67 \times \mathrm{SCA}-12$ & 3.18 & 1.06 \\
\hline 18-Corozal & IMC- $67 \times$ SCA- 12 & 2.95 & 0.83 \\
\hline 19 - Corozal & IMC- $67 \times$ SCA-12 & 2.74 & 0.88 \\
\hline 20 - Corozal & IMC- $67 \times \mathrm{SCA}-12$ & 2.43 & 1.03 \\
\hline 32 - Gurabo & IMC-67 $\times$ SCA-12 & 2.42 & 0.36 \\
\hline \multirow[t]{2}{*}{33 - Gurabo } & IMC- $67 \times$ SCA- 12 & 2.14 & 0.76 \\
\hline & & Mean & 0.86 \\
\hline
\end{tabular}

their families' first four years of full production. During the selection process the individual tree yield data were grouped under the normal probability curve, and those trees that consistently ranked two standard deviations above the population mean of each family and year were preliminarily selected as potential candidates. Since over $50 \%$ of the candidates at the selection sites of Corozal and Gurabo were clustered in only two replications, we proceeded to obtain a "weighted" yield value for each tree by dividing the yield of individual trees by the mean of their corresponding family replication. Although we may have skipped some high yielding trees, this procedure allowed the drawing of the final 40 selections from an increased number of replications. Additionally, five of the eight parental clones, UF-668, Pound-7, EET-400, SCA-12, and IMC-67, involved in the production of the original families (Irizarry and Rivera, 1998) were also grafted onto the same rootstock. Grafting plays an important role in the preservation of desirable genetic traits observed in cacao clonal selections and in maintaining homogeneity of the propagating materials (Ramadasan and Ahmed, 1984).

The 45 treatments were arranged in a randomized complete block design with six replications, each containing two experimental trees per treatment. The trees were planted in double rows, spaced with $2 \mathrm{~m}$ between adjacent rows and $2 \mathrm{~m}$ between trees in the row, forming a triangular array. A $3-\mathrm{m}$ alley was left every two rows to obtain a population density of 1,500 trees per hectare. The whole experiment was surrounded by two rows of buffer trees. 
The young trees were field planted about five months after grafting, and grown under the temporary shade of six-month-old plantains. The plantains were planted following an arrangement similar to that of the cacao trees. These were removed from the experimental site after the plant crop was harvested, about 16 months after planting.

Throughout the six-year evaluation period the trees were fertilized with a 15-5-20-5 ( $\mathrm{N}_{2} \mathrm{P}_{2} \mathrm{O}_{5}, \mathrm{~K}_{2} \mathrm{O}$ and $\left.\mathrm{MgO}\right)$ commercial fertilizer supplemented with $24.9 \mathrm{~kg} / \mathrm{t}$ of a granular microelements mixture. During the first two years the trees received 2279 of fertilizer per application four times per year. Thereafter, the rate per application was increased by $25 \%$ for every year the trees were in production. The plantains were fertilized separately from the cacao with a 10-5-20-5 formula at the rate of $450 \mathrm{~kg} / \mathrm{ha}$ per application at 2, 5,8 and 11 mo after planting.

Because of the continued use of nitrogen fertilization with ammonium sulfate, the experiment was limed at the rate of $4 \mathrm{t} / \mathrm{ha} / \mathrm{year}$, the lime applications concentrated under the tree canopy.

During the first two growing years the trees were pruned three times per year to assist in the formation of the canopy. In subsequent years the trees were pruned once a year to remove vertical shoots, low drooping branches, and to maintain a shrub-like architecture.

Weed growth between trees in the row and within adjacent rows was suppressed with post-emergence applications of glyphosate at the rate of $1 \% \mathrm{v} / \mathrm{v}$. The alleys between the double rows were mechanically weeded with a gasoline hand-held trimmer.

The white grub (Phyllophaga sp.), the most frequently observed injurious soil insect affecting cacao in Puerto Rico, was controlled with applications of aldicarb at the rate of $28 \mathrm{~g} /$ tree, and by drenching the tree trunk with a solution of oxamyl containing $20 \mathrm{ml}$ of the commercial product per $3.8 \mathrm{~L}$ of water. These compounds were applied in rotation every four months during the first three years of growth. Thereafter, the applications were alternated every six months.

The trees were harvested seven to eight times per year. At harvest the number of mature pods per tree was counted. The pods were opened and the wet beans were extracted, fermented and sun-dried to about 7\% moisture content. The pod index (number of pods needed to produce $1 \mathrm{~kg}$ of dry beans) was determined. Both the dry bean weight and pod index, obtained from the harvests of the first four years of full production (1994-1997), were statistically analyzed for all treatments by using the GLM procedure (SAS, 1987). These traits have been highly recommended as selection criteria in cacao (Enríquez et al., 1987; Soria, 1966) and the yield data obtained from three successive harvesting years are considered reliable in cacao evaluation experiments (Soria and Esquivel, 
1967). Mean separation for dry bean weight and pod index were determined with the Waller-Duncan test by using $\mathrm{P} \leq 0.01$ (SAS, 1987).

\section{RESULTS AND DISCUSSION}

Pod harvest began February 1993, and by the end of the second growing year, about $50 \%$ of the grafted trees were producing fruits. However, all trees reached full production during the third year in 1994 .

The clone $\times$ year interaction was highly significant when tested in a combined analysis. Yield was significantly affected by the maturity of the grafted trees (Table 2). An increase in tree maturity from three to six years of age significantly increased yield (dry bean weight) by an average annual rate of $16 \%$. It is expected that under normal growing conditions young cacao trees maintain annual yield increments until the trees reach a peak production between eight and ten years of age from seed planting. Thereafter, large yield fluctuations are expected to occur every other year (Wood and Lass, 1985). Pod index of older trees was significantly lower with a mean value of 25.9 after the trees surpassed three years of age.

Of the 40 clones selected for evaluation, only nine demonstrated superior yielding ability when compared with either the combined mean of the five parental clones (when the parents were not available for comparison) or to the mean of their highest yielding parent (Table 3). The highest yielding parent was UF-668 with a mean production of $0.94 \mathrm{~kg}$ / tree of dry beans, and the lowest was IMC-67 with $0.52 \mathrm{~kg} /$ tree. There were no significant differences among the nine best yielding clones. These clones yielded an average of $2,170 \mathrm{~kg} / \mathrm{ha}$ of dry beans per year during their first four years of full production. This amount is equivalent to a cumulative yield of $8,680 \mathrm{~kg} / \mathrm{ha}$ for six-year-old grafted clones.

TABLE 2.-Effect of tree maturity on the early yield and pod index of 45 cacao grafted clones grown at the Corozal substation during a six-year evaluation period, 1991-1997

\begin{tabular}{lccc}
\hline Age of grafted clone & Year harvest & $\begin{array}{c}\text { Mean dry bean } \\
\text { weight (kg/tree) }\end{array}$ & Pod index values \\
\hline Three years & 1994 & $0.71^{\mathrm{al}}$ & $32.3^{\mathrm{a}}$ \\
Four years & 1995 & $0.87^{\mathrm{b}}$ & $26.5^{\mathrm{b}}$ \\
Five years & 1996 & $1.13^{\mathrm{b}}$ & $26.0^{\mathrm{b}}$ \\
Six years & 1997 & $1.20^{\mathrm{d}}$ & $25.2^{\mathrm{b}}$ \\
\hline
\end{tabular}

'Means within a column followed by the same letter do not differ significantly at the 0.01 probability level. 
TABLE 3.-Yield comparison of nine superior cacao clones with the combined and individual mean of five of their corresponding parental clones grown under full sunlight and intrissive management at the Corozal substotion during $a$ four-year harvesting period, 1994-1997.

\begin{tabular}{|c|c|c|c|}
\hline \multirow[t]{2}{*}{$\begin{array}{l}\text { Clone number } \\
\text { and selection site }\end{array}$} & \multirow[t]{2}{*}{$\begin{array}{l}\text { Family pedigree } \\
\text { or parental clone }\end{array}$} & \multicolumn{2}{|c|}{ Mean dry bean weight per year } \\
\hline & & $\mathrm{kg} / \operatorname{tres}$ & $\mathrm{kg} / \mathrm{ha}$ \\
\hline 14 - Corozal & $\mathrm{SCA}-6 \times \mathrm{EET}-62$ & $1.60^{41}$ & $2,4.00$ \\
\hline 31 - Gurabo & SCA-6 $\times$ EET-62 & $1.54^{x}$ & 2,310 \\
\hline 34 - Yabucoa & UF-668 $\times$ Pound-7 & $1.48^{\prime \prime}$ & 2,220 \\
\hline 23 - Gurabo & UF- $668 \times$ Pound -7 & $1.15^{\prime \prime}$ & 2,175 \\
\hline 27 - Gurabo & ENT-400 $\times$ SCA- 12 & $1.43^{\prime \prime}$ & 2,145 \\
\hline 30 - Gurabo & $\mathrm{SCA}-6 \times \mathrm{EET}-62$ & $1.43^{a}$ & 2,145 \\
\hline 9 - Corozal & EET-400 $\times$ SCA- 12 & $1.38^{a}$ & 2,070 \\
\hline 15 - Corozal & SCA-6 × EET-62 & $1.36^{\mathrm{u}}$ & 2,040 \\
\hline \multirow[t]{7}{*}{1 - Corozal } & UF-668 $\times$ Pound- 7 & $1.35^{\prime \prime}$ & 2,025 \\
\hline & UF-668 & $0.94^{\prime \prime}$ & $1,4: 10$ \\
\hline & SCA-12 & $0.85^{3 \mathrm{c}}$ & 1,275 \\
\hline & Pound-7 & $0.79^{1 \mathrm{x}}$ & 1,185 \\
\hline & EET-400 & $0.57^{\circ}$ & 855 \\
\hline & IMC-67 & $0.52^{r}$ & 780 \\
\hline & Mean of parental clones & $0.73^{\text {be }}$ & $1,095.0$ \\
\hline
\end{tabular}

'Means within a column followed by the same letter do not differ significantly at the 0.01 probability level.

Since only nine of the initially selected clones significantly outyielded their parental clones, the probability of selecting superior genotypes from the initial population of 1,320 " $\mathrm{F}_{1}$ " trees representing the five families and the three locations in Puerto Rico (Irizarry and Rivera, 1998) was less than $1 \%$. This finding does not agree with the results obtained by other investigators (Batista, 1981; Esquivel and Soria, 1967), who have reported that in cacao families 8 to $14 \%$ of the population is composed of high yielding trees. Although all families were equally represented in the experiment, none of the 16 clones selected from families IMC-67 $\times$ SCA-12 and IMC-67 $\times$ UF-613 (Table 1) yielded significantly more than the combined mean of the five parental clones or the individual mean of parents IMC-67 and SCA-12 (Table 3). Since these two families were previously found to be significantly low yielders at the Gurabo substation (Irizarry and Rivera, 1998), we concluded that either one or both parents involved in these interclonal crosses lack combining ability and may be excluded from cacao improvement programs. 
The comparison of the initial yield (dry bean weight) recorded in the nine superior ungrafted selections (Table 1) with the final yield obtained after these clones were grafted and evaluated in replicated plots (Table 3 ), demonstrated that on the average only $45 \%$ of the initial yield was recovered after grafting. The 55\% difference was attributed to environmental effects, and perhaps to a degree of incompatibility between the scion and the rootstock. However, the existing relation between the scion and the rootstock in selections of the family EET-400 $\times$ SCA-12 did not favor a substantial overall yield recovery increase as compared with selections in other families (Table 1). Clone 31 had the highest yield recovery with $62 \%$, and clone 1 had the lowest with only $22 \%$. However, Clone 1 had a mean production of $6.1 \mathrm{~kg}$ of dry beans per year during the initial selection process (Table 1). The overall yield recovery of the 40 grafted selections was only $32 \%$.

At the termination of the experiment in 1997, nine clones had significantly higher pod index values when compared with the combined mean value of the five parental clones (Table 4). From this group, clones 13 and 31 had the highest pod index with a mean value of 43.0 . There

TABLE 4.-Pod index comparison of the uppermost ranked cacao clones with the combined and individual mean of fue of their corresponding parents The clones were grown under full-sunlight and intensive management at the Corozal Substation during a four-year harvesting period, 1994-1997.

\begin{tabular}{lll}
\hline $\begin{array}{l}\text { Clone number } \\
\text { and selection site }\end{array}$ & $\begin{array}{l}\text { Family pedigree } \\
\text { or parental clone }\end{array}$ & Pod index \\
\hline 13 - Corozal & SCA-6 $\times$ EET-62 & $43.8^{\mathrm{a}}$ \\
31 - Gurabo & SCA-6 $\times$ EET-62 & $42.2^{\mathrm{a}}$ \\
36 - Yabucoa & IMC-67 $\times$ UF-613 & $38.4^{\mathrm{b}}$ \\
30 - Gurabo & SCA-6 $\times$ EET-62 & $38.3^{\mathrm{b}}$ \\
16- Corozal & SCA-6 $\times$ EET-62 & $38.0^{\mathrm{b}}$ \\
15- Corozal & SCA-6 $\times$ EET-62 & $37.2^{\mathrm{b}}$ \\
14- Corozal & SCA-6 $\times$ EET-62 & $36.3^{\mathrm{b}}$ \\
27- Gurabo & EET-400 $\times$ SCA-12 & $35.6^{\mathrm{b}}$ \\
7 - Corozal & IMC-67 $\times$ UF-613 & $35.2^{\mathrm{b}}$ \\
& EET-400 & $45.3^{\mathrm{b}}$ \\
& Pound-7 & $30.8^{\mathrm{c}}$ \\
& SCA-12 & $29.3^{\mathrm{c}}$ \\
& IMC-67 & $22.5^{\mathrm{d}}$ \\
& UF-668 & $22.3^{\mathrm{d}}$ \\
& Mean of parental clones & $30.0^{\mathrm{c}}$ \\
\hline
\end{tabular}

'Means within a column followed by the same letter do not differ significantly at 0.01 probability level. 
were no significant differences among the other clones. The parental clone with the highest pod index was EET- 400 with a mean value of 45.3. This value was similar to the pod index of clones 13 and 31 but significantly higher than values from the other top ranked clones, including clone 27, one parent of which was EET-400 (Table 4).

Pod index has been considered an indirect measurement of pod size (Soria, 1966) and bean size (Wood and Lass, 1985). The higher the pod index the smaller the pod and consequently the bean size, and vice versa. Among the nine clones having a significantly higher pod index value, six $(13,14,15,16,30$ and 31) originated from the family SCA-6 $\times$ EET-62 (Table 4). Although the parental clones SCA-6 or EET-62 were not included in this experiment, the 39.3 mean pod index obtained from these six clones was similar to the value recorded from the same interclonal cross in previous studies (Irizarry and Rivera, 1998). Of the six clones from the family SCA- $6 \times$ EET-62 that contained a significantly higher pod index value, four (14, 15, 30 and 31) were also among the best dry bean producers (Table 3 ). This finding may indicate that the high yield potential of this family is related to high pod index or small pod size and consequently to small bean size. If this observation applies to other cacao families, simultaneous selection for high yield and large bean size may be troublesome. Esquivel and Soria (1967) evaluated progenies of three interclonal crosses and reported a significant positive correlation between high yield and high number of pods. Chocolate manufacturers prefer a large bean size, which they relate to quality.

The plantain yield obtained from the temporary intercropping with cacao was about 70,000 marketable fruits per hectare after estimating a $10 \%$ yield reduction due to late flowering of a few plants or the inability of the bunch to reach the mature green stage during the 16-month planting to harvest cycle. Considering that at the time the plantains were harvested the Puerto Rico Department of Agriculture had a guaranteed farm-gate price of $\$ 0.09$ per fruit, the gross income obtained from the temporary cacao-plantain intercropping was about $\$ 6,300$ per ha.

\section{LITERATURE CITED}

Batista, L. J., 1981. Evaluación de la capacidad productiva de 6 híbridos de cacao en. República Dominicana. Proc. $8^{\text {th }}$ Int. Cocoa Res. Conf., Cartagena, Colombia 713-717.

Enriquez, G. A. and J. V. Soria, 1984. Mejoramiento genétíco para resistencia a cinco enfermedades del cacao. Serie: Material de enseñanza No. 9, CATTE, Turrialba, Costa Rica.

Enríquez, G. A. and A. Paredes, 1985. El cultivo del cacao. Serie: Cultivos mayores No. 4, Editorial Univ. Estatal, San José, Costa Rica.

Enríquez, G. A., A. Cruz and A. Mora, 1987. Variabilidad de los componentes de producción y selección de plantas superiores por el método de índices en híbridos interclonales de cacao. Proc. 10 ${ }^{\text {th }}$ Int. Cocoa Res. Conf., Santo Domingo, República Dominicana 657-663. 
Esquivel, O and J. V. Soria, 1967. Algunos datos sobre la variabilidad de algunos componentes del rendimiento en poblaciones de hibridos interclonales de cacao. Cacao, CATIE, Turrialba, Costa Rica 12(4):1-8.

Hunter, J. R., 1990. The status of cacao (Theobroma cacao, Sterculiaceae) in the Western Hemisphere. Economic Botany 44(4):425-439.

Irizarry, H. and E. Rivera, 1998. Early yield of five cacao families at three locations in Puerto Rico. J. Agric. Univ. P.R. 82(3-4):163-171.

Ramadasan, K. and M. Y. Ahmed, 1984. Recent advances in vegetative propagation techniques of Theobroma cacao L. under Malaysian conditions. Proc. $8^{\text {th }}$ Int. Conf. on cocoa and coconuts, Kuala-Lampur (Malaysia) 1-15.

SAS Institute, 1987. SAS/STAT: Guide for personal computers, Version 6. Cary, NC.

Soria, J. V., 1966. Obtención de clones de cacao por el método de índices de selección. Revista Turrialba, CATTE, Costa Rica 16(2):119-124.

Soria, J. V. and O. Esquivel, 1967. Estudio preliminar sobre el período mínimo y confiable de producción en cacao para uso en experimentos. Cacao, CATIE, Turrialba, Costa Rica 12(4):9-14.

Wood, G. A. R. and R. A. Lass, 1985. Cocoa. Longman Group Limited, England and New York. 